\title{
The Ecology of Subaerial Biofilms in Dry and Inhospitable Terrestrial Environments
}

\author{
Federica Villa *(1) and Francesca Cappitelli \\ Department of Food, Environmental and Nutritional Sciences, Università degli Studi di Milano, Via Celoria 2, \\ 20133 Milano, Italy; francesca.cappitelli@unimi.it \\ * Correspondence: federica.villa@unimi.it; Tel.: +39-02-503-19121
}

Received: 31 July 2019; Accepted: 20 September 2019; Published: 23 September 2019

\begin{abstract}
The ecological relationship between minerals and microorganisms arguably represents one of the most important associations in dry terrestrial environments, since it strongly influences major biochemical cycles and regulates the productivity and stability of the Earth's food webs. Despite being inhospitable ecosystems, mineral substrata exposed to air harbor form complex and self-sustaining communities called subaerial biofilms (SABs). Using life on air-exposed minerals as a model and taking inspiration from the mechanisms of some microorganisms that have adapted to inhospitable conditions, we illustrate the ecology of SABs inhabiting natural and built environments. Finally, we advocate the need for the convergence between the experimental and theoretical approaches that might be used to characterize and simulate the development of SABs on mineral substrates and SABs' broader impacts on the dry terrestrial environment.
\end{abstract}

Keywords: subaerial biofilms; inhospitable conditions; environmental stresses; mineral-air interface; lab-scale models; symbiotic playground

\section{Introduction}

From the existence of extraterrestrial life in the universe to ancestral land colonization, from the drivers of primordial symbiosis to how to deal with antibiotic resistance, there are lots of phenomena we still largely do not know. Nevertheless, if at looked closely, all these big questions have a common denominator that is life in what humans consider inhospitable dry environments. With limited direct evidence, these issues remain scientifically problematic, but scientists can turn to indirect evidence to better address these questions. We think a good starting point would be the study of the adaption of microbial life (the principal biomass on Earth) to mineral substrates under environmental extremes, such as desiccation, radiation, high salt concentration, etc., which are features of dry terrestrial habitats.

The abiotic dry terrestrial environment is characterized by a patchy mosaic of air-exposed mineral substrates, ranging from natural (rocks) to man-made structures (e.g., stone heritage), subjected to a variety of environmental pressures and characterized by different physicochemical features. Although oligotrophic environments, mineral surfaces represent one of the main sources of micronutrients and ions potentially accessible to the biosphere [1]. Thus, it is not surprising to observe a thin veneer of densely packed microorganisms, called subaerial biofilms (SABs), that operate in self-organized structures on or within the top few centimeters of exposed soil and rocks [2]. In contrast to the planktonic mode of life, sessile aggregation provides cells with protection from various stresses including desiccation and antimicrobial agents and favors interplay among microorganisms and promotes social behavior through cooperation and the exchange of genetic material.

Interestingly, despite the inhospitable conditions in some habitats, the number of microorganisms in dry terrestrial environments is similar to the total number in marine habitats [3]. It also becoming increasingly clear that while the mineral-SAB interface is governed by microscale interactions played out 
within the mineralosphere, it exerts cascading bottom-up influences on ecosystem-scale processes such as primary production, the productivity and stability of food webs and biogeochemical cycling [1,4-6]. Thus, within the context of ecosystem function, the ecological relationships between minerals and SABs arguably represent some of the most important associations in dry terrestrial environments and land colonization, supporting a fundamental and seminal transition in microbial evolution [7].

Besides being nutrient-poor habitats, subaerial mineral substrates are often subjected to rapid changes in moisture availability, temperature and irradiation level, which promote the development of specialized SABs with efficient metabolic stress responses [8]. Thus, microorganisms within SABs must engage and coevolve with their neighbors and their physicochemical extracellular environment in order to adapt to diverse and fluctuating conditions.

Despite the abovementioned conditions and the low biomass, SAB communities are relatively stable [9] and display the community-level functional capability of maintaining a self-sustaining community [10]. The complex level of interspecies communication in SABs can be wholly appreciated by applying the current arsenal of omics-based technologies. Until recently, the study of SABs on mineral substrates has traditionally relied on the investigation of individually isolated microorganisms to make inferences about the entire community. However, our understanding of the SAB microbiota as an interactive ecosystem is still in its infancy. Although useful, it is now clear that studying communities through their individual components cannot adequately describe the collective behaviors and complex interplay that exist in multi-cellular communities under extreme conditions. Indeed, most of the time, there is a syntrophic chain in which several species contribute to the transformation of a compound [11].

Using life on air-exposed minerals as a model and taking inspiration from the mechanisms by which some microorganisms have adapted to the most inhospitable conditions, we applied "systems thinking" to illustrate the ecology of SABs inhabiting natural and built (stone heritage) environments. Finally, we advocate the need for the convergence between the experimental and theoretical approaches that might be used to characterize and model the development of SABs on mineral substrates and their broader impacts on the dry terrestrial environment.

Overall, we argue that solutions to environmental stresses would greatly benefit the knowledge we can gather from the ecology of SABs.

\section{Community Assembly at the Mineral-Air Interface}

Although one might assume that the dry terrestrial environment is generally inhospitable, it in fact hosts a large diversity of microbial life that preferentially accumulates along crevices and fissures, and the cleavage steps and edges of mineral surfaces [12-14].

Given the stark and oligotrophic nature of mineral substrates in many dry terrestrial environments, it is not surprising that SABs are supported by photosynthesis-based interactions (Figure 1) [2]. Carbon fixation by phototrophs drives chemoorganotrophic assemblages in this ecosystem. This points to the fundamental role of the mineralosphere as a key meeting place for shaping phototroph-chemoorganotroph partnerships [15]. The main characteristics of SABs inhabiting natural and built (stone heritage) environments are summarized in Table 1. It is possible to draw parallels among key biofilm attributes that drive geomicrobial processes in the topsoil, rock and man-made structures in an inhospitable environment by comparing the main phylogenetic groups, functional traits, biologically-driven processes and drought-resistance mechanisms, as reported in Table 1. 


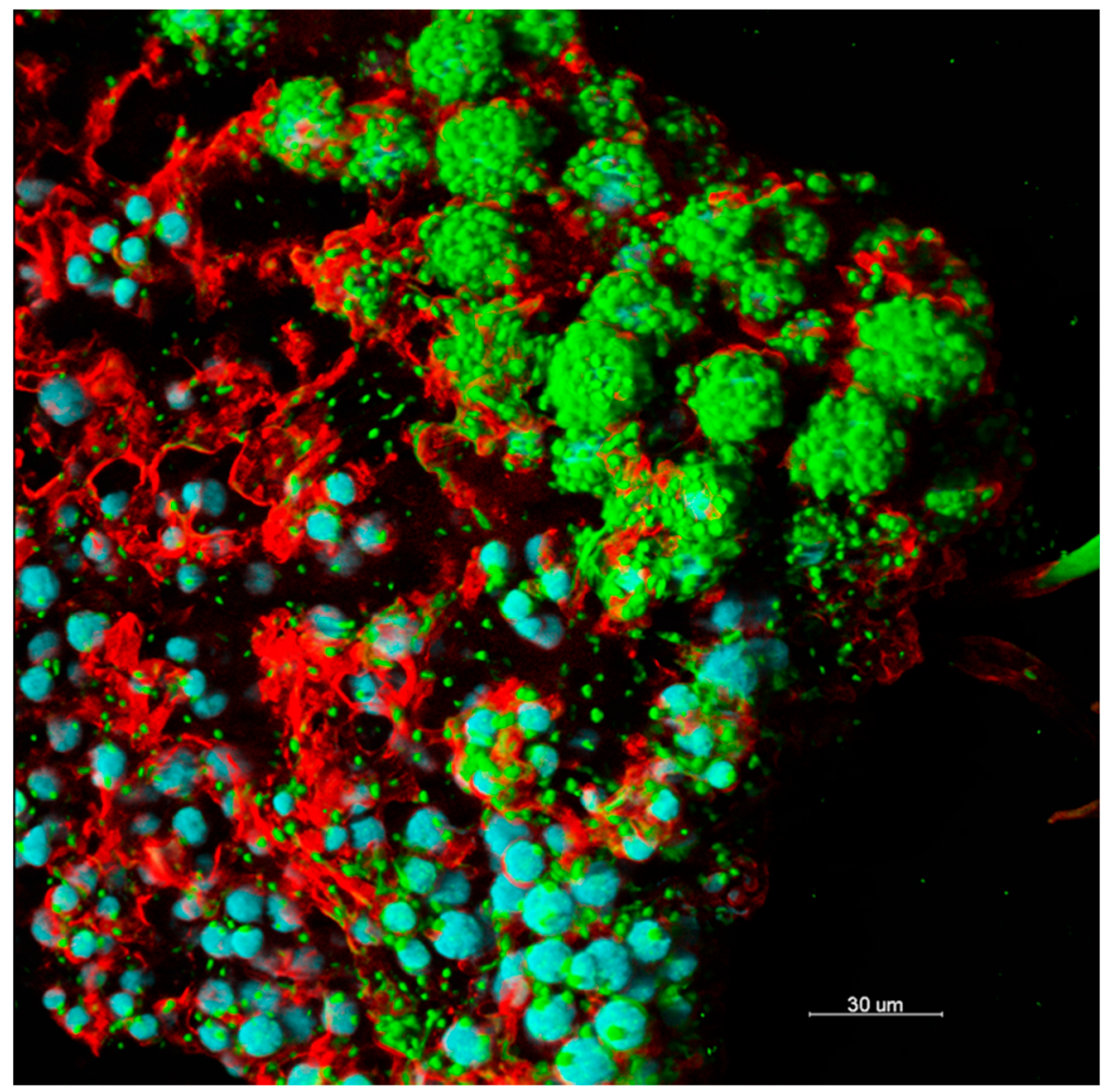

Figure 1. Confocal laser scanning imaging of a subaerial biofilm (SAB) growing on a stone monument. Blue, microcolonies of photoautotrophic microbes; green, chemotrophs; red, extracellular polymeric substances. 
Table 1. Main characteristics of SABs as biological soil crusts or inhabiting natural (desert rocks) and built (stone heritage) environments.

\begin{tabular}{|c|c|c|c|c|}
\hline & $\begin{array}{c}\text { Core Microbiome } \\
\text { (Metagenomic Studies) }\end{array}$ & Main Functional Traits & Biologically-Driven Processes & Mechanisms of Drought Resistance \\
\hline 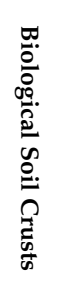 & $\begin{array}{l}\text { Bacteria: Cyanobacteria, } \\
\text { Actinobacteria, Acidobacteria, } \\
\text { Alpha-proteobacteria, and } \\
\text { Bacteroidetes } \\
\text { Fungi: Ascomycota, } \\
\text { Basidiomycota, and } \\
\text { Chytridiomycota } \\
\text { Archaea: Crenarchaeota } \\
\text { [16-21] }\end{array}$ & $\begin{array}{l}\text { Functional genes associated } \\
\text { with } C \text { degradation and } N \\
\text { cycling. }\end{array}$ & $\begin{array}{l}\text { Modulating } C \text { and } N \text { heterogeneity and cycling. } \\
\text { Increasing the capture of nutrient-rich dust. } \\
\text { Modulating, surface albedo, water fluxes and } \\
\text { erosion. } \\
\text { Influencing soil fertility and plant } \\
\text { establishment patterns. } \\
\text { [22-24] }\end{array}$ & $\begin{array}{l}\text { EPSs act as a repository for water and stabilize } \\
\text { desiccation-tolerant enzymes and molecules. } \\
\text { Activation of a non-radioactive cyclic electron transfer route } \\
\text { during photosinthesis to minimize oxidative damage. } \\
\text { Synthesis and degradation of osmolytes are used to balance the } \\
\text { changing water potential. } \\
\text { [23-25] }\end{array}$ \\
\hline 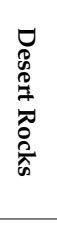 & $\begin{array}{l}\text { Bacteria: Actinobacteria, } \\
\text { Cyanobacteria, Proteobacteria, } \\
\text { and Chloroflexi } \\
\text { Fungi: Ascomycota } \\
\text { Archaea: Crenarchaeota } \\
\text { [26-28] }\end{array}$ & $\begin{array}{l}\text { Transition metal-related } \\
\text { molecular functions such as } \\
\text { manganese ion binding and iron } \\
\text { ion binding. } \\
{[29,30]}\end{array}$ & $\begin{array}{l}\text { Modulating } C \text { and } N \text { heterogeneity and cycling. } \\
\text { Clogging the surface rock pores through } \\
\text { secretion of extracellular polymeric substances } \\
\text { (EPSs), lowering evaporation and slowing salt } \\
\text { crystallization. } \\
\text { [31] }\end{array}$ & $\begin{array}{l}\text { EPSs act as a repository for water and stabilize } \\
\text { desiccation-tolerant enzymes and molecules. } \\
\text { Synthesis of heat-shock proteins and chaperons. Production of } \\
\text { antioxidant enzymes, DNA damage repair systems, and } \\
\text { UV-absorbing pigments. } \\
\text { Dormant cells. } \\
\text { [23,32] }\end{array}$ \\
\hline 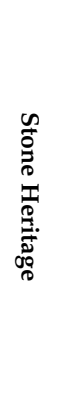 & $\begin{array}{l}\text { Bacteria: Cyanobacteria, } \\
\text { Actinobacteria Proteobacteria, } \\
\text { Bacteroidetes, Acidobacteria, } \\
\text { and Chloroflexi } \\
\text { Fungi: Ascomycota } \\
\text { Archaea: Euryarchaeota and } \\
\text { Crenarchaeota }\end{array}$ & $\begin{array}{l}\text { Functional genes associated } \\
\text { with } \mathrm{C}, \mathrm{N} \text { and } \mathrm{S} \text { cycling } \\
\text { autotrophic carbon fixation and } \\
\text { mineral transformation } \\
\text { processes. }\end{array}$ & $\begin{array}{l}\text { Modulating } C \text { and } N \text { heterogeneity and cycling. } \\
\text { Weakening of the mineral lattice through } \\
\text { wetting and drying cycles and sub-sequent } \\
\text { expansion and contraction of the EPS matrix. } \\
\text { Dissolving minerals through the excretion of } \\
\mathrm{H}^{+}, \mathrm{CO}_{2} \text {, organic and inorganic acids, } \\
\text { siderophores and other metabolites. } \\
\text { Mediating the formation of minerals. } \\
\text { Regulating water fluxes in the stone. } \\
\text { Increasing hydrophobicity of the surface. } \\
\text { Incorporation of mineral grains into the } \\
\text { biofilm. } \\
\text { [14] }\end{array}$ & $\begin{array}{l}\text { EPSs act as a repository for water and stabilize } \\
\text { desiccation-tolerant enzymes and molecules. } \\
\text { Synthesis of antioxidant. } \\
\text { Synthesis and degradation of osmolytes to balance the changing } \\
\text { water potential. } \\
\text { Dormant cells. }\end{array}$ \\
\hline
\end{tabular}


The next-generation sequencing of SABs on mineral substrates is becoming increasingly available, which has enabled a more detailed understanding of the composition and diversity patterns of microbial communities within these ecosystems. Although SABs inhabiting desert rocks and stone heritage can be highly specific to their lithic substrate, they were all dominated by the same four main phyla, Cyanobacteria, Actinobacteria, Chloroflexi and Proteobacteria [16,33,34,37-39]. While the phylum Ascomycota is the most representative of the fungal communities, the archaeal community is the least represented in SABs on mineral surfaces.

Overall, the results revealed taxa associated with survival under extreme conditions such as salinity (e.g., Halococcus, Kocuria, Salinimicrobium, Pontibacter, Halobacterium, Marinobacter, and Halomarina), UV radiation (e.g., Thuepera, Deinococcus, Coccomyxa, Rubrobacter, Chroococcidiopsis, Spirosoma, Scytonema, Blastococcus, and Modestobacter), acidic conditions (e.g., Apatococcus, Acidobacteriaceae, Beijerinciaceae and Methylocystaceae), alkaline conditions (e.g., Spirosoma, Rubellimicrobium and Truepera) and low water availability (e.g., Chroococcidiopsis, Knufia, Leptolyngbya, Sarcinomyces, Rubrobacter, Capnobotryella, and Scytonema) $[17,35,40-42]$. Other genera indicated the capacity to cycle nitrogen (e.g., Thiobacillus, Malikia, Ochrobactrum, Nitrososphaera, Nitrospira, Novosphingobium, and Nitrobacter), cycle sulfur (e.g., Thioclava, Thiobacillus, Rhodovulum, and Desulfuromonas), autotrophically fix carbon (e.g., Chroococcidiopsis, Leptolyngbya, Nostoc, Trebouxiophyceae, Phormidium, Aurantiamonas, Thiobacillus, Thioclava, Rhodobacter, and Acidimicrobium), utilize minerals such as iron and manganese (e.g., Aurantimonas, Acidimicrobium, and Ferrimicrobium) and bioprecipitate minerals (e.g., Bacillus, Stenotrophomonas, Pseudomonas, and Crosiella) $[10,29,30,35,42]$.

Despite the sequencing efforts and advanced analytical tools, the complete genomes of microbial species from the topsoil, rock and man-made structures are scarce (Table 2). Genome sequences from cultivated and uncultivated microorganisms will allow deep investigations of the physiological traits that enable survival under inhospitable conditions, including the ability of these microorganisms to respond to future perturbations such as climate change and human impacts.

Furthermore, the scientific community is still far from understanding the mechanisms behind the formation of SAB communities on mineral substrates. How do SAB communities assemble? What are the main drivers for structuring $\mathrm{SAB}$ communities on minerals?

By sampling tombstones across three continents, Brewer and Fierer [36] demonstrated that the type of stone had a major effect on the overall composition of the SAB communities. In line with this finding, shot gun metagenomics analyses identified gene categories that were differentially abundant across two lithotypes, granite and limestone [36]. Granite samples harbored acidophilic bacteria and showed gene pathways linked to both acid resistance and acid production, cell movement and substrate transport as well as amino acid synthesis. By contrast, limestone surfaces hosted radiation-resistant bacteria with neutral to alkaline $\mathrm{pH}$ growth ranges as well as lichen-associated taxa. Limestone communities were enriched in genes related to carbon-fixing pathways, UV resistance and vitamin and cofactor synthesis.

$\mathrm{Li}$ and colleagues [9] studied the epilithic SABs of archeological sites located at different areas of China over a two-year period. They investigated whether biofilm communities, which were geographically and chronologically separated, showed distinct taxonomy or functionality. Findings indicated that no substantial differences in terms of community structures were observed among the different locations, while microhabitat was the major factor affecting the stone microbiome. Functional prediction analyses indicated that the ATP-binding cassette transporter (ABC transporter) system was characteristic of the deterioration-associated microbiome, indicating that the complex exchange of amino acid, molecules and iron complex is affected [9]. Furthermore, samples showing plaques of white deposits on the surface were characterized by metabolic pathways involving mineral absorption, calcium signaling, extracellular polymeric substance (EPS) production and membrane transport proteins, suggesting the occurrence of $\mathrm{CaCO}_{3}$ precipitation processes [9]. 
A recent study carried out on SABs colonizing the passage of Lascaux Cave revealed that mineral substrates were important drivers structuring both the total (DNA) and the metabolically active (RNA) microbial communities, more so than the presence of black discoloration and the seasonality did [43].

Substrate-dependent patterns of community assembly have been observed in biological soil crusts and cryptoendolith communities from the Colorado Plateau Desert, as well as in hypolithic communities colonizing the meteorites found in Nullarbor Plain, Australia [44,45]. By studying the diversity and community composition of endoliths from four different lithic substrates collected in the Atacama Desert, Meslier et al. [46] showed how SAB assembly was driven by substrate properties. Among the substrate properties, rock architecture and water retention capabilities are the main factors influencing microbial community compositions.

Altogether these findings suggest that distinct mineral substrates from the same climate regime and geographic area harbor distinct microbial communities.

Table 2. Complete genomes of microbial species from the topsoil, rock and man-made structures.

\begin{tabular}{cl}
\hline & \multicolumn{1}{c}{ Sequenced Genomes } \\
\hline & Microvirga sp. Strain BSC39 [47] \\
& Aquincola tertiaricarbonis [48] \\
Biological Soil Crusts & Microcoleus vaginatus FGP-2 [49] \\
& Massilia sp. Strain BSC265 [50] \\
& Bacillus sp. Strain BSC154 [51] \\
& Knufia petricola [52] \\
& Sphingomonas sp. strain AntH11 [53] \\
& Rachicladosporium antarcticum CCFEE 5527 and Rachicladosporium sp. \\
& CCFEE 5018 [54] \\
& Halorubrum sp. SAH-A6 [55] \\
Desert Rocks & Nakamurella lactea [56] \\
& Cryomyces antarcticus [57] \\
& Hassallia byssoidea strain VB512170 [58] \\
& Scytonema millei VB511283 [59] \\
& Tolypothrix boutellei strain VB521301 [60] \\
& Blastococcus saxobsidens DD2 [61] \\
& Modestobacter marinus strain BC501 [62] \\
\hline
\end{tabular}

\section{Biological Interactions in SABs: A Symbiotic Playground}

SABs have been the focus of numerous studies on microbial community structure and function, improving our understanding of their relative trophic simplicity and pertinence in ecosystem service maintenance $[16,40,63]$.

Metagenomic studies of SABs have revealed stress response and nutrient cycling genes to fix carbon and nitrogen under fluctuating and inhospitable conditions, as well as genes involved in microbial competition and cooperation [64-66].

Lichens, associations of a fungus and a chlorophyll-containing partner (either green algae or cyanobacteria, or both), represent iconic examples of symbiosis at the mineral-air interface. Thanks to this association, the production of energy via carbon dioxide fixation provided by photobiont is enhanced by the sheltering structures offered by the fungal partner. However, this classical view has been challenged by recent omics investigations, which revealed a functional contribution of bacteria associated with lichens, corroborating the understanding of lichens as stratified biofilms [67] and characterized by multi-species symbiosis [68,69]. Grube et al. [70] provided strong evidence that the bacterial microbiome is involved in multiple aspects of the symbiotic system, including (i) nutrient provision, especially nitrogen, phosphorous and sulfur, (ii) resistance against biotic stress factors (iii) resistance against abiotic factors, (iv) biosynthesis of vitamins and hormones, (v) detoxification of metabolites, and (vi) degradation of older lichen thallus parts. Furthermore, recently, integrated metaproteomics analyses showed that lichen symbionts are involved in specific activities. Fungal 
symbionts produce transport protein-regulating vesicle traffic, cyanobacteria synthetize nitrogenase and glutamine oxoglutarate aminotransferase involved in nitrogen fixation, algae express proteins functioning in photosynthesis, and bacterial enzymes are responsible for methanol/C1-compound metabolism as well as CO-detoxification [71].

Within SABs, mutualistic interactions between autotrophs and heterotrophs can occur beside lichen symbiosis. Geological evidence of interspecies interactions between cyanobacteria and heterotrophs dates to a million years ago, and the cohesiveness of such interactions is demonstrated by the paucity of axenic cyanobacteria strains [72]. More recently, Couradeau et al. [73] described the mutualistic relationship between the dominant member of the biocrust microbiome, the non-nitrogen-fixing cyanobacterium Microcoleus vaginatus, and the diazotrophic copiotrophic heterotrophs based on a $\mathrm{C}$ for $\mathrm{N}$ exchange. In fact, while $M$. vaginatus offers organic carbon, it relies on other bacteria for its nitrogen needs. Thus, $M$. vaginatus carries its own built-in nitrogen fixation "microbiome module" in order to increase its fitness as a colonizer of $\mathrm{N}$-depleted soils [74].

A study carried out by Villa and colleagues [11] explained cooperative interactions in SAB communities by revealing the functional interplay occurring among four main microbial groups inhabiting a tombstone located in a polluted environment. It was observed that the organic carbon produced by cyanobacteria during photosynthesis fuels sulfate-reducing bacteria (SRB) and sulfur-oxidizing bacteria (SOB) growth, while the photosynthetic oxygen is consumed by $\mathrm{SOB}$, generating the anaerobic environment for SRB and anoxygenic phototrophic sulfur bacteria. Furthermore, SOB activity quickly removes $\mathrm{S}^{2-}$, the metabolic product of SRB, which could inhibit cyanobacteria and, at higher concentrations, also SRB. Genes for assimilatory sulfate reduction, mineralization of organic sulfur compounds, and oxidation of sulphide and thiosulphate were detected in the metagenome of hypolithic SABs from the Namib desert, suggesting an extensive capacity for sulfur cycling [65]. Zanardini et al. [10] demonstrated that SABs on stonework are potentially self-sustaining ecosystems able to cycle essential elements such as carbon, nitrogen and sulfur. Through functional gene analyses, the researchers found a complete nitrogen cycle with nitrogen-fixing cyanobacteria, nitrifying and denitrifying bacteria as well as the presence of autotrophic carbon fixation capacity and sulfur-oxidizing bacteria and sulfate-reducing bacteria.

However, the structurally and functional complexity of SAB communities make species-specific observations of behavior technically challenging. The use of synthetic consortia maintained under controlled environments is attractive to infer mechanisms that mediate symbiotic relationships such as metabolic coupling and acclimation to partnership.

The unicellular cyanobacterium Synechocystis sp. strain PCC 6803 and the chemoheterotroph Escherichia coli K12 were used to reproduce a laboratory-scale dual species SAB on limestone [74]. Findings demonstrated that cyanobacterial biomass and stress resistance increased as a result of heterotrophic partnership. Furthermore, the cyanobacterial matrix offered carbon and energy sources for E. coli growth, while the heterotroph promoted cyanobacteria growth by providing key metabolites and the scavenging of waste products $[72,74,75]$. The involvement of cooperative behavior may suggest the participation of quorum sensing signaling molecules in such responses. Quorum sensing (QS) is a cell-to-cell communication system depending on population density able to coordinate community behavior. Quorum sensing involves production of and response to diffusible or secreted signals called autoinducers. Sharif et al. [76] reported that the epilithic cyanobacterium Gloeothece produces $\mathrm{N}$-octanoyl-homoserine lactone as a signal molecule, altering gene expression in response in an autoinducer-like manner. Through microscopic investigations, Villa et al. [2,74] revealed that the EPS matrix was not concentrated in only one single colony but extended along the mineral substrata, interconnecting cellular clusters together. Interestingly, it has been observed that the "calling distance" of quorum sensing can extend up to $78 \mu \mathrm{m}$ between single species biofilms [77]. Thus, it is likely that communication and cooperation among segregated microcolonies can occur by diffusion of metabolites and QS molecules through the EPS network. 
Species-resolved transcriptomic analyses of binary consortia composed by a cyanobacterium and an obligate aerobic heterotroph revealed that the phototroph responded to the heterotrophic partnership by altering the expression of core genes involved in photosynthesis, carbon uptake/fixation, vitamin synthesis, ribosomal proteins, and scavenging of reactive oxygen species [78-81]. El Moustaid et al. [22] studied how photosynthesis can be conflicted by photorespiration in a dual species consortium composed of a phototroph and a heterotroph. Results showed that a phototroph-heterotroph consortium can increase biomass by recycling photorespiration byproducts.

Overall, the above results suggest that $\mathrm{SAB}$ communities prefer mutually neutral or even beneficial associations, expanding metabolic abilities and improving resource utilization and stress responses over that of its individual members [8]. That is why SABs have been considered as symbiotic playgrounds [8].

\section{Stress Resistance and Resilience of SABs}

SABs are likely equipped to cope with frequent, often daily, stress factors such as hydration/dehydration cycles, extreme fluctuations in temperature and irradiance as well as biocide treatments. Understanding the mechanisms behind stress responses in SABs is instrumental to identify the ecological and physiological drivers of biofilm formation, resistance (insensitivity to disturbance) and resilience (the rate of recovery after disturbance) in a changing environment. So far, little is understood at community level, while several studies are available for single isolated terrestrial species.

\subsection{Physical Stresses}

SABs show a pronounced three-dimensional stratification, where, in most cases, phototrophs dominate closer to the biofilm-air interface in contact with the external environment [2]. Thus, studying self-protection strategies of phototrophs is important as the vertically lower-positioned microorganisms of a SAB may not have ever been exposed to some physical stresses thanks to the efficient response of these specialized microorganisms on the top of the biofilm [25]. Photosynthesis is affected by drought and UV-B irradiation. Studies on Leptolyngbya ohadii as well as Microcoleus sp. isolated from BSCs showed the activation of a nonradioactive cyclic electron transfer route during photosynthesis that minimized oxidative damage in desiccation-tolerant cyanobacteria $[82,83]$. During the desiccation of L. ohadii, a decrease in the transcript levels of genes involved in light harvesting, photosynthetic metabolism, protein biosynthesis and cell division was detected [84]. Phormidium tenue responded to UV-B radiation reducing photosynthetic activity, while increasing the production of antioxidant enzymes, DNA damage repair systems, and UV-absorbing pigments to protect itself from the cell damage caused by the radiation [85]. Recently, Wadsworth et al. [86] investigated the survival of Gloeocapsa sp. in extraterrestrial conditions. The findings demonstrated that metabolically inactive cells surrounded viable cells, providing protection against environmental stress such as UV radiation. Thus, viable cells can bury themselves in disordered aggregates of sheathed inactive cells, which also provided a protected niche for other bacteria that survived in space [86].

As expansion and shrinkage could cause mechanical stress upon desiccation, a $\beta$-galactosidase produced by the terrestrial cyanobacterium Nostoc flagelliforme, the transcription of which is regulated by moisture cycles, has been demonstrated to affect EPS density [87].

The amount of proteins has been shown to be modulated in response to stresses although both a decrease and an increase have been claimed. Steven et al. [18] observed an increased protein production from the same number of mRNA molecules, while [32] microcolonial fungi (MCF) exposed to desiccation/rehydration events, demonstrated a loss of proteins. Wang et al. [88] performed a comparative transcriptome analysis of the lichen-forming fungus Endocarpon pusillum to elucidate its drought response and found an up-regulation of genes coping with proteins misfolding. The researchers also observed the differential expression of genes involved in sugar synthesis, suggesting that under desiccation the mycobiont reduced monosaccharides and increased polysaccharides.

Murik et al. [89] also suggested that the synthesis and degradation of various osmolytes are used to balance the changing water potential in L. ohadii. Interestingly, nitrification in the enrichments of 
some Negev desert samples was performed up to $400 \mathrm{mM} \mathrm{NaCl}$ (2.3\% salt), a concentration close to that of seawater [90]. It is known that salt accumulation increases extracellular osmolarity as desiccation.

\subsection{Chemical Stresses}

Zhang et al. [91] investigated the importance of salinity along a natural salinity gradient in the Gurbantunggut Desert, Northwestern China. The researchers proved that microbial diversity was linearly reduced with salt accumulation, but community dissimilarity greatly increased with salinity differences. The latter counterintuitive finding has been explained by the fact that unrelated taxa also coexist in dry environments and the competitive exclusion of some closely related taxa.

Despite some manuscripts on salinity, the resistance and resilience of SABs to chemical stressors have been focused on the use of biocides in conservation treatments of stone monuments [92]. However, the main question we pose is how can we tell whether a biocide treatment is working against SABs?

In this respect, Villa and co-workers [74] investigated the susceptibility of a dual-species SAB to the quaternary ammonium solution $\mathrm{D} / 2$ through time lapse confocal laser scanning microscopy. By quantifying the fluorescence loss of both green fluorescence protein (GFP)-tagged heterotrophic cells and autofluorescent phototrophic cells, this technique permitted the direct visualization of cell inactivation patterns in biofilm structure during biocide action (Figure 2, Video S1). The extent of fluorescence loss ranged from $46 \%$ to $80 \%$ depending on the bacterial group considered, suggesting an intrinsic resistance to traditional biocidal active substances and a different level of susceptibility towards the chemical compound applied.
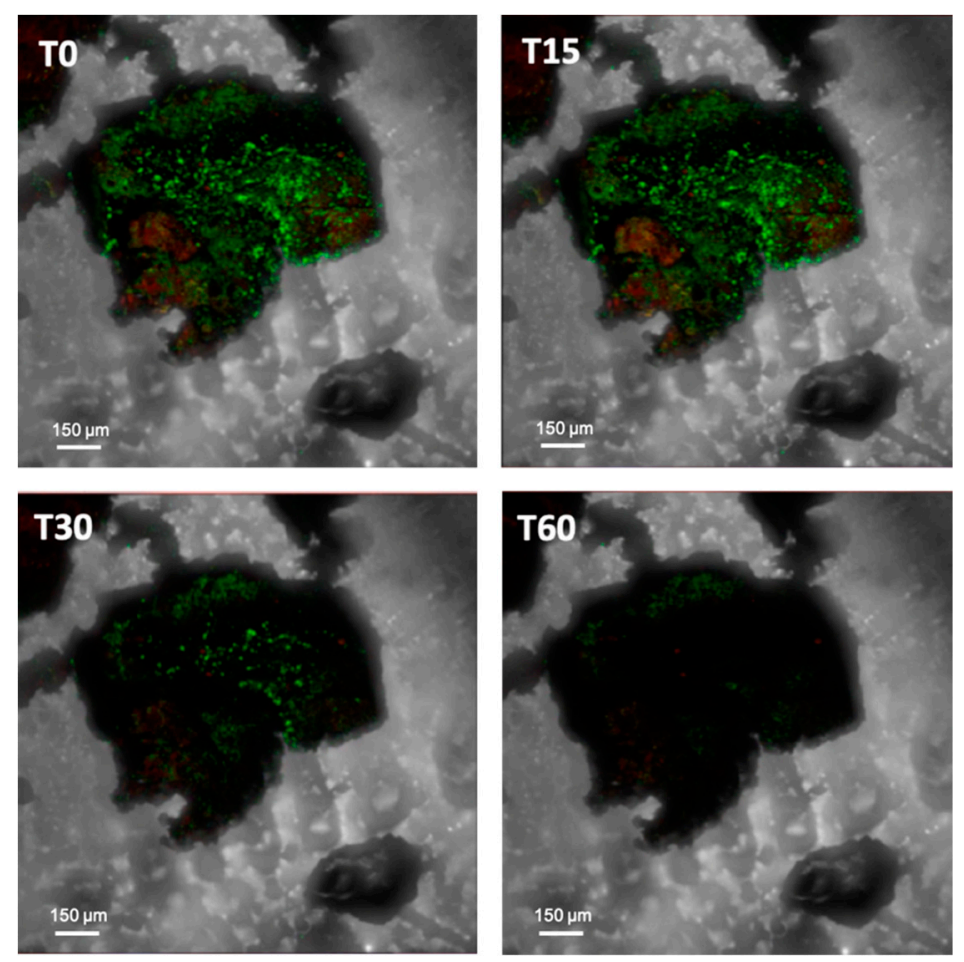

Figure 2. Antimicrobial effectiveness of $\mathrm{D} / 2$ solution. Real-time loss in cell viability over time in the presence of the biocide treatment (treated sample). Chemotrophs have been visualized in green by Calcein AM, which detects metabolically active cells. Phototrophs have been visualized in red by using the natural autofluorescence of the photosynthetic pigments. It is possible to observe the presence of green and red signals after the treatment, indicating cells resistant to the biocide.

Another question addresses which microorganisms the selected biocides are efficiently targeting. Urzì et al. [93] compared the change occurring to the SAB communities in one site of the Catacombs of Domitilla before and after a treatment with a mixture of quaternary ammonium compounds and 
actylisothiazolone applied for a one-month period. The results clearly showed that cyanobacteria were slightly affected by the treatment, while the heterotrophic bacteria changed drastically in terms of diversity. In fact, the synthesis and excretion of extracellular polymeric substances, mainly produced by cyanobacteria, can provide a barrier against the penetration of biocidal compounds [94,95]. Nowicka-Krawczyk and colleagues [96] investigated the effect of silver nanoparticles (AgNPs) on the most frequently occurring species of green algae in subaerial biofilms. Overall, their findings demonstrated that although all the tested AgNP concentrations affected the growth of the aerophytic algae in a dose-dependent manner (with a biomass reduction ranging from $26 \%$ to $68 \%$ ), the inhibition was time dependent and, in some cases, it was reversed after two weeks from the treatment. Gambino et al. [97] exposed fungal biofilms, grown with a colony biofilm approach, to two concentrations $(0.25 \%$ and $0.5 \%$ ) of zinc oxide NPs (ZnO-NPs) for 10 days. It was shown that the growth rate of some fungal biofilms at both $0.25 \%$ and $0.5 \%$ concentrations was severely slowed down by the ZnO-NPs, while the treatments did not successfully work for Aspergillus niger biofilms, its growth being promoted by the lower $\mathrm{ZnO}-\mathrm{NPs}$ concentration.

In addition, $\mathrm{SAB}$ communities may become less sensitive or even resistant to the biocides, exerting a harmful impact to the object. The Lascaux Caves is an emblematic example of situations in which a series of biocide treatments over time (antibiotics, formol, various products based on benzalkonium chloride and isothiazolinone) triggered the development of white patina caused by Fusarium solani, the growth of resistant Pseudomonas fluorescens strains and the growth of melanized fungi such as Ochroconis lascauxensis, Ochroconis anomala and Exophiala castellanii [98].

The resistance of SABs is clearly not caused by a single factor, but rather by several mechanisms acting in concert, ensuring the survival of biofilm cells in the face of even the most aggressive antimicrobial treatment regimens. The mechanisms include, among others, poor biocide penetration, nutrient limitation and slow growth, adaptive stress responses, the formation of persister cells and various actions of specific genetic determinants of biocide resistance and tolerance [99].

EPSs are polymers that can interact with biocides by inactivating the molecule through delaying their diffusion or chemically react with them [100]. Furthermore, in SABs, the EPS matrix provides heterogeneous nucleation sites for calcium carbonate precipitations [101]. It has been observed that many photosynthetic microorganisms inside SAB communities can bury themselves under calcite crystals, which results in an extra barrier against the biocidal action [93].

Taken together, the results suggest the pervasiveness and diversity of resistance in non-pathogenic bacteria, such as those retrieved in SABs, despite the lack of human intervention. The reservoir of resistance elements might be related to the resistance and resilience of SABs to antimicrobial agents.

\section{Lab-Scale Systems and Mathematical Models: Methods to Study SABs}

Simplified laboratory-based model systems become instrumental for exploring SAB performance and for the application of omics-based approaches to dissect subcellular pathways and regulatory networks. Furthermore, the simplicity and controllability of model systems provides a stark contrast to the complexity and inaccessibility of field systems. The model systems enable the researchers to test hypotheses about the ecology of SABs under different environmental conditions, and to establish the plausibility of mechanisms governing biogeochemical transformations [2].

Despite the success in reproducing complex phototrophic SABs [102-104], these communities are difficult to analyze at the molecular level since omics technologies require microorganisms with available genetic and physiological information [105]. To overcome the limitation offered by complex phototrophic SABs, an elegant dual-species model biofilm was developed. The model system comprised the cyanobacterium Nostoc punctiforme strain ATCC 29,133 (PCC 73102) as a phototroph, and the well-studied marble-derived isolated microcolonial fungus A95 Knufia petricola (syn. Sarcinomyces petricola) [106] as a heterotrophic component [8]. Through this model, Seiffert and colleagues [107,108] successfully studied the biological impact of the consortium on weathering granite and related minerals in a new setting of a geomicrobiologically modified percolation column. Villa et al. [74] proposed a 
laboratory model of SABs composed of the unicellular cyanobacterium Synechocystis sp. strain PCC 6803 and the chemoheterotroph E. coli K12 (Figure 3). Villa and colleagues' model system was able to mirror the main features of biofilms inhabiting lithic substrates, such as morphology, syntrophic interactions, survival to desiccation stress and biocide tolerance.

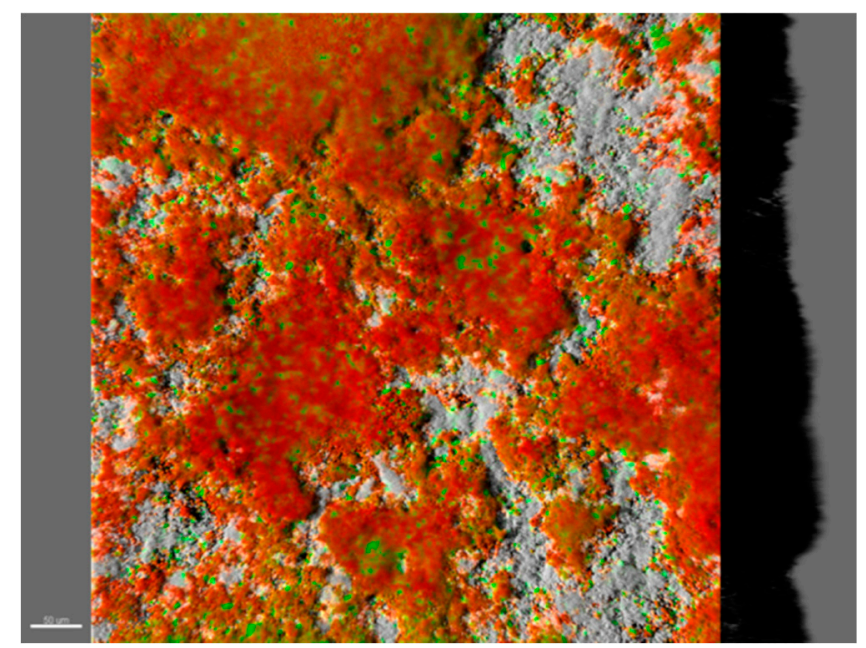

Figure 3. The 3D reconstruction of cell aggregates in a dual-species SAB model system. Color key: $E$. coli cells, green (green fluorescence protein (GFP)); Synechocystis cells, red (autofluorescence); reflection from inorganic materials, grey.

Despite the importance of SAB models, quantitative studies using mathematical or computational approaches are rare. In this respect, through a model, it has been shown that under periodic stress, Pseudomonas aeruginosa planktonic cells preferentially attach to existing aggregates rather than to a bare surface. In inhospitable environments, this phenomenon can favor a mixed biofilm development [109].

The first work concerning a conceptual model of rock dwelling fungal biofilms formed on exposed surfaces of solid rocks was proposed by Chertov et al. [110]. By simulating the growth of a single microcolony on a rock surface, the researchers proved whether the fungal growth is influenced by the environmental factors and organic compounds. Process-based models have also been developed for biological soil crusts of lichens and mosses, to predict processes that control carbon uptake (photosynthesis, respiration, water uptake and evaporation), global biogeochemical cycles and weathering [19,111-114]. Recently, Kim and Or [63] reported a mechanistic model that considers the physical and chemical processes shaping the functioning of biocrust communities that interact and respond to cycles of hydration, light, and temperature. The model results showed not only the distribution and composition of microbial functional groups over vertical gradients of light, temperature, and substrates, but also carbon and nitrogen cycling within the biocrust. Furthermore, the findings based on an acid-base equilibrium predicted the spatial and temporal activity of microbial functional groups. Self-organization explains why biocrusts can host high biodiversity even under very dry conditions like deserts.

\section{Conclusions and Future Directions}

The next-generation sequencing of SABs on mineral substrates is becoming increasingly available and shows the dominance of four main phyla, Cyanobacteria, Actinobacteria, Chloroflexi and Proteobacteria. Thus, SAB communities living in mineral environments benefit from goods exchange and labor division in long-term partnerships between members of different groups.

Subaerial biofilms in inhospitable environments are multi-component open ecosystems sensitively tuned to the external environment, which provides not only nutrients, moisture and space, but also physical and chemical stressors that are drivers of biofilm formation, resistance and resilience. Despite 
the significance of model systems in SAB studies, works on this topic are rare, and most of them are based on mono-species biofilms.

Despite the ubiquity of SABs and their effects over natural and man-made ecosystems, there are still many unanswered questions regarding their physiology and behavior as ecological systems. Future research should be aimed at opening up the 'black box' of SAB biomes for unravelling the assembly of microbial communities (diversity) and their response to extreme conditions in a spatio-temporal scale (function) in line with the extracellular physical and chemical environment. For instance, the dispersal and invasion of SAB microorganisms across local, regional and continental scales are poorly investigated, although they are a major factor in shaping the biogeography of SABs. Unravelling the biogeographic patterns of SABs could help in improving large-scale ecosystem models of greenhouse gas fluxes and the response of these fluxes to further changes in the global climate and atmospheric composition.

At present, stress response mechanisms at community assembly levels are neglected but they have the potential to reveal novel adaptive traits in SAB microorganisms and a better understanding of the colonization processes of mineral substrates under stress conditions. This understanding will help to reduce uncertainties about the responses of microorganisms to a change in environment and will enable that knowledge to be incorporated into future predictive models of climate change and some terrestrial feedbacks.

It will also be intriguing to establish to what extent biogeological processes and interactions with the environmental conditions can be predicted by the characteristic of SAB communities (either the composition or functional markers), and whether a unifying theory can be developed to explain the role of $S A B$ in many different inhospitable dry terrestrial ecosystems. Thus, understanding interactions among SABs, mineral substrates and the changing environment is crucial to addressing ecological and biogeochemical questions, as well as to developing tools for predicting what their potential is to influence climate feedbacks across ecosystems and along environmental gradients.

Despite advances in our knowledge of the physiology of SABs, we are still far from achieving the level of fundamental understanding of their dynamics and functions that is needed to predict and manipulate $\mathrm{SAB}$ behavior in dry terrestrial environments. SAB dynamics and functions could be very important, since SABs could either participate in climate change mitigation or exacerbate anthropogenic climate change. Omics-based approaches allow us to catalogue the structure and function of SABs to an unprecedented level of detail. Omics data, along with environmental and substrate information, represent a snapshot of the SAB ecosystem. The key challenge now is to incorporate biological (omics), environmental, chemical and geological data into mathematical models, in order to offer a system-level understanding of the phenomenon. To achieve this level of predictive understanding, integration between mathematical models, with a basis in mechanistic understanding, and controlled experiments is required. Thus, increased interaction between empiricists and theoreticians, as well as the development of standardized SAB models, which can act as testbeds for the development of experimental and modeling approaches, is strongly encouraged.

Understanding how SABs cope with extreme conditions can help elucidate the potential for life to exist in a context of environmental changes and even beyond our planet.

Supplementary Materials: The following are available online at http://www.mdpi.com/2076-2607/7/10/380/s1, Video S1: Antimicrobial effectiveness of D/2 solution. Real-time loss in cell viability over time in the presence of the biocide treatment (treated sample).

Author Contributions: F.V. and F.C. conceived and wrote the manuscript.

Funding: The open access article processing charge was covered by the project LINEA2 2018-AZIONE A funded by the Department of Food, Environmental and Nutritional Sciences, Università degli Studi di Milano.

Acknowledgments: The authors would like to thank the Center for Biofilm Engineering at Montana State University for use of the microscope facilities, which were supported by funding obtained from the NSF-MRI Program and the M.J. Murdock Charitable Trust.

Conflicts of Interest: The authors declare no conflict of interest. 


\section{References}

1. Uroz, S.; Kelly, L.C.; Turpault, M.P.; Lepleux, C.; Frey-Klett, P. The mineralosphere concept: Mineralogical control of the distribution and function of mineral-associated bacterial communities. Trends Microbiol. 2015, 23, 751-762. [CrossRef] [PubMed]

2. Villa, F.; Stewart, P.S.; Klapper, I.; Jacob, J.M.; Cappitelli, F. Subaerial biofilms on outdoor stone monuments: Changing the perspective toward an ecological framework. BioScience 2016, 66, 285-294. [CrossRef]

3. Flemming, H.C.; Wuertz, S. Bacteria and archaea on Earth and their abundance in biofilms. Nat. Rev. Microbiol. 2019, 17, 247-260. [CrossRef] [PubMed]

4. Chiquoine, L.P.; Abella, S.R.; Bowker, M.A. Rapidly restoring biological soil crusts and ecosystem functions in a severely disturbed desert ecosystem. Ecol. Appl. 2016, 26, 1260-1272. [CrossRef] [PubMed]

5. Gulotta, D.; Villa, F.; Cappitelli, F.; Toniolo, L. Biofilm colonization of metamorphic lithotypes of a renaissance cathedral exposed to urban atmosphere. Sci. Total Environ. 2018, 639, 1480-1490. [CrossRef] [PubMed]

6. Chen, N.; Liu, X.; Zheng, K.; Zhang, C.; Liu, Y.; Lu, K.; Jia, R.; Zhao, C. Ecohydrological effects of biocrust type on restoration dynamics in drylands. Sci. Total. Environ. 2019, 687, 527-534. [CrossRef]

7. Wu, H.; Fang, Y.; Yu, J.; Zhang, Z. The quest for a unified view of bacterial land colonization. ISME J. 2014, 8, 1358-1369. [CrossRef]

8. Gorbushina, A.A.; Broughton, W.J. Microbiology of the atmosphere-rock interface: How biological interactions and physical stresses modulate a sophisticated microbial ecosystem. Annu. Rev. Microbiol. 2009, 63, 431-450. [CrossRef]

9. Li, Q.; Zhang, B.; Yang, X.; Ge, Q. Deterioration-associated microbiome of stone monuments: Structure, variation, and assembly. Appl. Environ. Microbiol. 2018, 84, e02680-17. [CrossRef]

10. Zanardini, E.; May, E.; Purdy, K.J.; Murrell, J.C. Nutrient cycling potential within microbial communities on culturally important stoneworks. Environ. Microbiol. Rep. 2019, 11, 147-154. [CrossRef]

11. Villa, F.; Vasanthakumar, A.; Mitchell, R.; Cappitelli, F. RNA-based molecular survey of biodiversity of limestone tombstone microbiota in response to atmospheric sulfur pollution. Lett Appl Microbiol. 2015, 60, 92-102. [CrossRef] [PubMed]

12. Walker, J.J.; Pace, N.R. Endolithic microbial ecosystems. Annu. Rev. Microbiol. 2007, 61, 331-347. [CrossRef] [PubMed]

13. Casanova Municchia, A.; Percario, Z.; Caneva, G. Detection of endolithic spatial distribution in marble stone. J. Microsc. 2014, 256, 37-45. [CrossRef] [PubMed]

14. Gadd, G.M. Geomicrobiology of the built environment. Nat Microbiol. 2017, 28, 16275. [CrossRef] [PubMed]

15. Wierzchos, J.; Cámara, B.; de Los Ríos, A.; Davila, A.F.; Sánchez Almazo, I.M.; Artieda, O.; Wierzchos, K.; Gómez-Silva, B.; McKay, C.; Ascaso, C. Microbial colonization of Ca-sulfate crusts in the hyperarid core of the Atacama Desert: Implications for the search for life on Mars. Geobiology 2011, 9, 44-60. [CrossRef] [PubMed]

16. Mogul, R.; Vaishampayan, P.; Bashir, M.; McKay, C.P.; Schubert, K.; Bornaccorsi, R.; Gomez, E.; Tharayil, S.; Payton, G.; Capra, J.; et al. Microbial community and biochemical dynamics of biological soil crusts across a gradient of surface coverage in the central Mojave Desert. Front. Microbiol. 2017, 8, 1974. [CrossRef] [PubMed]

17. Swenson, T.L.; Karaoz, U.; Swenson, J.M.; Bowen, B.P.; Northen, T.R. Linking soil biology and chemistry in biological soil crust using isolate exometabolomics. Nat. Commun. 2018, 9, 19. [CrossRef] [PubMed]

18. Steven, B.; Belnap, J.; Kuske, C.R. Chronic physical disturbance substantially alters the response of biological soil crusts to a wetting pulse, as characterized by metatranscriptomic sequencing. Front. Microbiol. 2018, 9, 2382. [CrossRef] [PubMed]

19. Liu, Y.; Zhao, L.; Wang, Z.; Liu, L.; Zhang, P.; Sun, J.; Wang, B.; Guang Song, G.; Li, X. Changes in functional gene structure and metabolic potential of the microbial community in biological soil crusts along a revegetation chronosequence in the Tengger Desert. Soil Biol. Biochem. 2018, 126, 40-48. [CrossRef]

20. Zhao, L.; Li, X.; Yuan, S.; Liu, Y. Shifts in community structure and function of ammonia-oxidizing archaea in biological soil crusts along a revegetation chronosequence in the Tengger Desert. Sci. Cold Arid Reg. 2019, 11, 139-149.

21. Nunes da Rocha, U.; Cadillo-Quiroz, H.; Karaoz, U.; Rajeev, L.; Klitgord, N.; Dunn, S.; Truong, V.; Buenrostro, M.; Bowen, B.P.; Garcia-Pichel, F.; et al. Isolation of a significant fraction of non-phototroph diversity from a desert Biological Soil Crust. Front. Microbiol. 2015, 6, 277. [CrossRef] [PubMed] 
22. El Moustaid, F.; Carlson, R.P.; Villa, F.; Klapper, I. Photorespiration and rate synchronization in a phototroph-heterotroph microbial consortium. Processes 2017, 5, 11. [CrossRef]

23. Rossi, F.; De Philippis, R. Role of cyanobacterial exopolysaccharides in phototrophic biofilms and in complex microbial mats. Life 2015, 5, 1218-1238. [CrossRef] [PubMed]

24. Bar-Eyal, L.; Eisenberg, I.; Faust, A.; Raanan, H.; Nevo, R.; Rappaport, F.; Krieger-Liszkay, A.; Sétif, P.; Thurotte, A.; Reich, Z.; et al. An easily reversible structural change underlies mechanisms enabling desert crust cyanobacteria to survive desiccation. Biochim. Biophys Acta 2015, 1847, 1267-1273. [CrossRef] [PubMed]

25. Karsten, U.; Holzinger, A. Green algae in alpine biological soil crust communities: Acclimation strategies against ultraviolet radiation and dehydration. Biodivers. Conserv. 2014, 23, 1845-1858. [CrossRef] [PubMed]

26. Esposito, A.; Ahmed, E.; Ciccazzo, S.; Sikorski, J.; Overmann, J.; Holmström, S.J.; Brusetti, L. Comparison of rock varnish bacterial communities with surrounding non-varnished rock surfaces: Taxon-specific analysis and morphological description. Microb. Ecol. 2015, 70, 741-750. [CrossRef] [PubMed]

27. Lang-Yona, N.; Maier, S.; Macholdt, D.S.; Müller-Germann, I.; Yordanova, P.; Rodriguez-Caballero, E.; Jochum, K.P.; Al-Amri, A.; Andreae, M.O.; Fröhlich-Nowoisky, J.; et al. Insights into microbial involvement in desert varnish formation retrieved from metagenomic analysis. Environ. Microbiol. Rep. 2018, 10, $264-271$. [CrossRef] [PubMed]

28. Le, P.T.; Makhalanyane, T.P.; Guerrero, L.D.; Vikram, S.; Van de Peer, Y.; Cowan, D.A. Comparative metagenomic analysis reveals mechanisms for stress response in hypoliths from extreme hyperarid deserts. Genome Biol. Evol. 2016, 8, 2737-2747. [CrossRef]

29. Alnaimat, S.; Shattal, S.A.; Althunibat, O.; Alsbou, E.; Amasha, R. Iron (II) and other heavy-metal tolerance in bacteria isolated from rock varnish in the arid region of Al-jafer basin, Jordan. Biodiversitas 2017, 18, 1250-1257. [CrossRef]

30. Krinsley, D.H.; DiGregorio, B.; Dorn, R.I.; Razink, J.; Fisher, R. Mn-Fe-Enhancing budding bacteria in century-old rock varnish, Erie Barge Canal, New York. J. Geol. 2017, 125, 317-336. [CrossRef]

31. Wang, X.; Zeng, L.; Wiens, M.; Schloßmacher, U.; Jochum, K.P.; Schröder, H.C.; Müller, W.E.G. Evidence for a biogenic, microorganismal origin of rock varnish from the Gangdese Belt of Tibet. Micron 2011, 42, 401-411. [CrossRef] [PubMed]

32. Zakharova, K.; Tesei, D.; Marzban, G.; Dijksterhuis, J.; Wyatt, T.; Sterflinger, K. Microcolonial fungi on rocks: A life in constant drought? Mycopathologia 2013, 175, 537-547. [CrossRef] [PubMed]

33. Chimienti, G.; Piredda, R.; Pepe, G.; van der Werf, I.D.; Sabbatini, L.; Crecchio, C.; Ricciuti, P.; D’Erchia, A.M.; Manzari, C.; Pesole, G. Profile of microbial communities on carbonate stones of the medieval church of San Leonardo di Siponto (Italy) by Illumina-based deep sequencing. Appl. Microbiol. Biotechnol. 2016, 100, 8537-8548. [CrossRef] [PubMed]

34. Li, Q.; Zhang, B.; He, Z.; Yang, X. Distribution and diversity of bacteria and fungi colonization in stone monuments analyzed by high-throughput sequencing. PLOS ONE 2016, 11, e0163287. [CrossRef] [PubMed]

35. Zhang, X.; Ge, Q.; Zhu, Z.; Dengc, Y.; Gu, J.D. Microbiological community of the Royal Palace in Angkor Thom and Beng Mealea of Cambodia by Illumina sequencing based on $16 \mathrm{~S}$ rRNA gene. Int. Biodeterior. Biodegradation 2018, 134, 127-135. [CrossRef]

36. Brewer, T.E.; Fierer, N. Tales from the tomb: The microbial ecology of exposed rock surfaces. Environ. Microbiol. 2018, 20, 958-970. [CrossRef]

37. Pointing, S.B. Hypolithic Communities. In Biological Soil Crusts: An Organizing Principle in Drylands; Weber, B., Büdel, B., Belnap, J., Eds.; Springer International Publishing: Cham, Switzerland, 2016; pp. 199-213.

38. Wierzchos, J.; Casero, M.C.; Artieda, O.; Ascaso, C. Endolithic microbial habitats as refuges for life in polyextreme environment of the Atacama Desert. Curr. Opin. Microbiol. 2018, 43, 124-131. [CrossRef] [PubMed]

39. Abed, R.M.M.; Tamm, A.; Hassenrück, C.; Al-Rawahi, A.N.; Rodríguez-Caballero, E.; Fiedler, S.; Maier, S.; Weber, B. Habitat-dependent composition of bacterial and fungal communities in biological soil crusts from Oman. Sci. Rep. 2019, 9, 6468. [CrossRef]

40. Gaylarde, C.; Baptista-Neto, J.A.; Ogawa, A.; Kowalski, M.; Celikkol-Aydin, S.; Beech, I. Epilithic and endolithic microorganisms and deterioration on stone church facades subject to urban pollution in a sub-tropical climate. Biofouling 2017, 33, 113-127. [CrossRef]

41. Lebre, P.H.; De Maayer, P.; Cowan, D.A. Xerotolerant bacteria: Surviving through a dry spell. Nat. Rev. Microbiol. 2017, 15, 285-296. [CrossRef] 
42. Mazzoli, R.; Giuffrida, M.G.; Pessione, E. Back to the past: Find the guilty bug-microorganisms involved in the biodeterioration of archeological and historical artifacts. Appl. Microbiol. Biotechnol. 2018, 102, 6393-6407. [CrossRef] [PubMed]

43. Alonso, L.; Creuzé-des-Châtelliers, C.; Trabac, T.; Dubost, A.; Moënne-Loccoz, Y.; Pommier, T. Rock substrate rather than black stain alterations drives microbial community structure in the passage of Lascaux Cave. Microbiome 2018, 6, 216. [CrossRef] [PubMed]

44. Lee, K.C.; Archer, S.D.J.; Boyle, R.H.; Lacap-Bugler, D.C.; Belnap, J.; Pointing, S.B. Niche filtering of bacteria in soil and rock habitats of the Colorado Plateau Desert, Utah, USA. Front. Microbiol. 2016, 7, 1489. [CrossRef] [PubMed]

45. Tait, A.W.; Gagen, E.J.; Wilson, S.A.; Tomkins, A.G.; Southam, G. Microbial populations of stony meteorites: Substrate controls on first colonizers. Front. Microbiol. 2017, 8, 1-14. [CrossRef] [PubMed]

46. Meslier, V.; Casero, M.C.; Dailey, M.; Wierzchos, J.; Ascaso, C.; Artieda, O.; McCullough, P.R.; DiRuggiero, J. Fundamental drivers for endolithic microbial community assemblies in the hyperarid Atacama Desert. Environ. Microbiol. 2018, 20, 1765-1781. [CrossRef] [PubMed]

47. Bailey, A.C.; Kellom, M.; Poret-Peterson, A.T.; Noonan, K.; Hartnett, H.E.; Raymond, J. Draft genome sequence of Microvirga sp. Strain BSC39, isolated from biological soil crust of Moab, Utah. Genome Announc. 2014, 2, e01197-14. [CrossRef] [PubMed]

48. Tang, K.; Yuan, B.; Zeng, Y.; Jia, L.; Feng, F. Draft genome sequence of Aquincola tertiaricarbonis MIMtkpLc11, an aerobic anoxygenic phototrophic bacterial strain isolated from biological soil crusts. Microbiol. Resour. Announc. 2018, 7, e01085-18. [CrossRef] [PubMed]

49. Starkenburg, S.R.; Reitenga, K.G.; Freitas, T.; Johnson, S.; Chain, P.S.; Garcia-Pichel, F.; Kuske, C.R. Genome of the cyanobacterium Microcoleus vaginatus FGP-2, a photosynthetic ecosystem engineer of arid land soil biocrusts worldwide. J. Bacteriol. 2011, 193, 4569-4570. [CrossRef] [PubMed]

50. Bailey, A.C.; Kellom, M.; Poret-Peterson, A.T.; Noonan, K.; Hartnett, H.E.; Raymond, J. Draft genome sequence of Massilia sp. strain BSC265, isolated from biological soil crust of Moab, Utah. Genome Announc. 2014, 2, e01199-14. [CrossRef] [PubMed]

51. Bailey, A.C.; Kellom, M.; Poret-Peterson, A.T.; Noonan, K.; Hartnett, H.E.; Raymond, J. Draft genome sequence of Bacillus sp. strain BSC154, isolated from biological soil crust of Moab, Utah. Genome Announc. 2014, 2, e01198-14. [CrossRef] [PubMed]

52. Tesei, D.; Tafer, H.; Poyntner, C.; Piñar, G.; Lopandic, K.; Sterflinger, K. Draft genome sequences of the black rock fungus Knufia petricola and its spontaneous nonmelanized mutant. Genome Announc. 2017, 5, e01242-17. [CrossRef] [PubMed]

53. Gunnigle, E.; Ramond, J.B.; Guerrero, L.D.; Makhalanyane, T.P.; Cowan, D.A. Draft genomic DNA sequence of the multi-resistant Sphingomonas sp. strain AntH11 isolated from an Antarctic hypolith. FEMS Microbiol. Lett. 2015, 362, 37.

54. Coleine, C.; Masonjones, S.; Selbmann, L.; Zucconi, L.; Onofri, S.; Pacelli, C.; Stajich, J.E. Draft genome sequences of the Antarctic endolithic fungi Rachicladosporium antarcticum CCFEE 5527 and Rachicladosporium sp. CCFEE 5018. Genome Announc. 2017, 5, e00397-17. [CrossRef] [PubMed]

55. Gibtan, A.; Woo, M.; Oh, D.; Park, K.; Lee, H.S.; Sohn, J.H.; Lee, D.W.; Shin, J.K.; Lee, S.J. Draft genome sequence of the extremely halophilic Halorubrum sp. SAH-A6 isolated from rock salts of the Danakil depression, Ethiopia. Genom. Data 2016, 10, 30-32. [CrossRef] [PubMed]

56. Nouioui, I.; Göker, M.; Carro, L.; Montero-Calasanz, M.D.; Rohde, M.; Woyke, T.; Kyrpides, N.C.; Klenk, H.P. High quality draft genome of Nakamurella lactea type strain, a rock actinobacterium, and emended description of Nakamurella lactea. Stand. Genomic. Sci. 2017, 12, 4. [CrossRef] [PubMed]

57. Sterflinger, K.; Lopandic, K.; Pandey, R.V.; Blasi, B.; Kriegner, A. Nothing special in the specialist? Draft genome sequence of Cryomyces antarcticus, the most extremophilic fungus from Antarctica. PLoS ONE 2014, 9, e109908. [CrossRef] [PubMed]

58. Sen, D.; Chandrababunaidu, M.M.; Singh, D.; Sanghi, N.; Ghorai, A.; Mishra, G.P.; Madduluri, M.; Adhikary, S.P.; Tripathy, S. Draft genome sequence of the terrestrial cyanobacterium Scytonema millei VB511283, isolated from Eastern India. Genome Announc. 2015, 3, e00009-e00015. [CrossRef] [PubMed]

59. Singh, D.; Chandrababunaidu, M.M.; Panda, A.; Sen, D.; Bhattacharyya, S.; Adhikary, S.P.; Tripathy, S. Draft genome sequence of cyanobacterium Hassallia byssoidea Strain VB512170, Isolated from Monuments in India. Genome Announc. 2015, 3, e00064-15. [CrossRef] [PubMed] 
60. Chandrababunaidu, M.M.; Singh, D.; Sen, D.; Bhan, S.; Das, S.; Gupta, A.; Adhikary, S.P.; Tripathy, S. Draft genome sequence of Tolypothrix boutellei strain VB521301. Genome Announc. 2015, 3, e00001-e00015. [CrossRef] [PubMed]

61. Chouaia, B.; Crotti, E.; Brusetti, L.; Daffonchio, D.; Essoussi, I.; Nouioui, I.; Sbissi, I.; Ghodhbane-Gtari, F.; Gtari, M.; Vacherie, B.; et al. Genome sequence of Blastococcus saxobsidens DD2, a stone-inhabiting bacterium. J. Bacteriol. 2012, 194, 2752-2753. [CrossRef]

62. Normand, P.; Gury, J.; Pujic, P.; Chouaia, B.; Crotti, E.; Brusetti, L.; Daffonchio, D.; Vacherie, B.; Barbe, V.; Médigue, C.; et al. Genome sequence of radiation-resistant Modestobacter marinus strain BC501, a representative actinobacterium that thrives on calcareous stone surfaces. J. Bacteriol. 2012, 194, 4773-4774. [CrossRef]

63. Kim, M.; Or, D. Hydration status and diurnal trophic interactions shape microbial community function in desert biocrusts. Biogeosciences 2017, 14, 5403-5424. [CrossRef]

64. Ortiz, M.; Legatzki, A.; Neilson, J.W.; Fryslie, B.; Nelson, W.M.; Wing, R.A.; Soderlund, C.A.; Pryor, B.M.; Maier, R.M. Making a living while starving in the dark: Metagenomic insights into the energy dynamics of a carbonate cave. ISME J. 2014, 8, 478-491. [CrossRef] [PubMed]

65. Vikram, S.; Guerrero, L.D.; Makhalanyane, T.P.; Le, P.T.; Seely, M.; Cowan, D.A. Metagenomic analysis provides insights into functional capacity in a hyperarid desert soil niche community. Environ. Microbiol. 2016, 18, 1875-1888. [CrossRef] [PubMed]

66. Goordial, J.; Davila, A.; Greer, C.W.; Cannam, R.; DiRuggiero, J.; McKay, C.P.; Whyte, L.G. Comparative activity and functional ecology of permafrost soils and lithic niches in a hyper-arid polar desert. Environ. Microbiol. 2016, 19, 443-458. [CrossRef] [PubMed]

67. Krumbein, D.M.; Paterson, G.A.; Zavarzin, W.E. Fossil and Recent Biofilms: A Natural History of Life on Earth; Springer: Dordrecht, The Netherlands, 2013.

68. Aschenbrenner, I.A.; Cernava, T.; Berg, G.; Grube, M. Understanding microbial multi-species symbioses. Front. Microbiol. 2016, 7, 180. [CrossRef] [PubMed]

69. Grube, M.; Wedin, M. Lichenized fungi and the evolution of symbiotic organization. Microbiol. Spectr. 2016, 4,6 .

70. Grube, M.; Cernava, T.; Soh, J.; Fuchs, S.; Aschenbrenner, I.; Lassek, C.; Wegner, U.; Becher, D.; Riedel, K.; Sensen, C.W.; et al. Exploring functional contexts of symbiotic sustain within lichen-associated bacteria by comparative omics. ISME J. 2015, 9, 412-424. [CrossRef] [PubMed]

71. Eymann, C.; Lassek, C.; Wegner, U.; Bernhardt, J.; Fritsch, O.A.; Fuchs, S.; Otto, A.; Albrecht, D.; Schiefelbein, U.; Cernava, T.; et al. Symbiotic interplay of fungi, algae, and bacteria within the lung lichen Lobaria pulmonaria L. Hoffm. as assessed by state-of-the-art metaproteomics. J. Proteome Res. 2017, 16, 2160-2173. [CrossRef]

72. Cole, J.K.; Hutchison, J.R.; Renslow, R.S.; Kim, Y.-M.; Chrisler, W.B.; Engelmann, H.E.; Dohnalkova, A.C.; Hu, D.; Metz, T.O.; Fredrickson, J.K.; et al. Phototrophic biofilm assembly in microbial-mat-derived unicyanobacterial consortia: Model systems for the study of autotroph-heterotroph interactions. Front. Microbiol. 2014, 5, 109. [CrossRef]

73. Couradeau, E.; Giraldo-Silva, A.; De Martini, F.; Garcia-Pichel, F. Spatial segregation of the biological soil crust microbiome around its foundational cyanobacterium, Microcoleus vaginatus, and the formation of a nitrogen-fixing cyanosphere. Microbiome 2019, 7, 55. [CrossRef] [PubMed]

74. Villa, F.; Pitts, B.; Lauchnor, E.; Cappitelli, F.; Stewart, P.S. Development of a laboratory model of a phototroph-heterotroph mixed-species biofilm at the stone/air interface. Front. Microbiol. 2015, 6, 1251. [CrossRef] [PubMed]

75. Valverde, A.; Makhalanyane, T.P.; Seely, M.; Cowan, D.A. Cyanobacteria drive community composition and functionality in rock-soil interface communities. Mol. Ecol. 2015, 24, 812-821. [CrossRef] [PubMed]

76. Sharif, D.I.; Gallon, J.; Smith, C.J.; Dudley, E. Quorum sensing in Cyanobacteria: N-octanoyl-homoserine lactone release and response, by the epilithic colonial cyanobacterium Gloeothece PCC6909. ISME J. 2008, 2, 1171-1182. [CrossRef] [PubMed]

77. Gantner, S.; Schmid, M.; Dürr, C.; Schuhegger, R.; Steidle, A.; Hutzler, P.; Langebartels, C.; Eberl, L.; Hartmann, A.; Dazzo, F.B. In situ quantitation of the spatial scale of calling distances and population density-independent $\mathrm{N}$-acylhomoserine lactone-mediated communication by rhizobacteria colonized on plant roots. FEMS Microbiol. Ecol. 2006, 56, 188-194. [CrossRef] [PubMed] 
78. Bernstein, H.C.; Carlson, R.P. Microbial consortia engineering for cellular factories: In vitro to in silico systems. Comput. Struct. Biotechnol. J. 2012, 3, e201210017. [CrossRef]

79. Beliaev, A.S.; Romine, M.F.; Serres, M.; Bernstein, H.C.; Linggi, B.E.; Markillie, L.M.; Isern, N.G.; Chrisler, W.B.; Kucek, L.A.; Hill, E.A.; et al. Inference of interactions in cyanobacterial-heterotrophic co-cultures via transcriptome sequencing. ISME J. 2014, 8, 2243-2255. [CrossRef] [PubMed]

80. Biller, S.J.; Coe, A.; Chisholm, S.W. Torn apart and reunited: Impact of a heterotroph on the transcriptome of Prochlorococcus. ISME J. 2016, 10, 2831-2843. [CrossRef]

81. Bernstein, H.C.; McClure, R.S.; Thiel, V.; Sadler, N.C.; Kim, Y.M.; Chrisler, W.B.; Hill, E.A.; Bryant, D.A.; Romine, M.F.; Jansson, J.K.; et al. Indirect interspecies regulation: Transcriptional and physiological responses of a cyanobacterium to heterotrophic partnership. mSystems 2017, 2, e00181-16. [CrossRef]

82. Ohad, I.; Raanan, H.; Keren, N.; Tchernov, D.; Kaplan, A. Light-Induced changes within photosystem II protects Microcoleus sp. in biological desert sand crusts against excess light. PLoS ONE 2010, 5, e11000. [CrossRef]

83. Raanan, H.; Oren, N.; Treves, H.; Berkowicz, S.M.; Hagemann, M.; Pade, N.; Keren, N.; Kaplan, A. Simulated soil crust conditions in a chamber system provide new insights on cyanobacterial acclimation to desiccation. Environ. Microbiol. 2016, 18, 414-426. [CrossRef] [PubMed]

84. Oren, N.; Raanan, H.; Murik, O.; Keren, N.; Kaplan, A. Dawn illumination prepares desert cyanobacteria for dehydration. Curr. Biol. 2017, 27, R1056-R1057. [CrossRef] [PubMed]

85. Wang, G.; Deng, S.; Liu, J.; Ye, C.; Zhou, X.; Chen, L. Cell damage caused by ultraviolet B radiation in the desert cyanobacterium Phormidium tenue and its recovery process. Ecotoxicol. Environ. Saf. 2017, 144, 315-320. [CrossRef] [PubMed]

86. Wadsworth, J.; Rettberg, P.; Cockell, C.S. Aggregated cell masses provide protection against space extremes and a microhabitat for hitchhiking co-inhabitants. Astrobiology 2019, 19, 995-1007. [CrossRef] [PubMed]

87. Liu, W.; Cui, L.; Xu, H.; Zhu, Z.; Gao, X. Flexibility-rigidity coordination of the dense exopolysaccharide matrix in terrestrial cyanobacteria acclimated to periodic desiccation. Appl Environ. Microbiol. 2017, 83, e01619-17. [CrossRef] [PubMed]

88. Wang, Y.; Zhang, X.; Zhou, Q.; Zhang, X.; Wei, J. Comparative transcriptome analysis of the lichen-forming fungus Endocarpon pusillum elucidates its drought adaptation mechanisms. Sci. China Life Sci. 2015, 58, 89-100. [CrossRef] [PubMed]

89. Murik, O.; Oren, N.; Shotland, Y.; Raanan, H.; Treves, H.; Kedem, I.; Keren, N.; Hagemann, M.; Pade, N.; Kaplan, A. What distinguishes cyanobacteria able to revive after desiccation from those that cannot: The genome aspect. Environ. Microbiol. 2017, 19, 535-550. [CrossRef] [PubMed]

90. Nejidat, A. Nitrification and occurrence of salt-tolerant nitrifying bacteria in the Negev desert soils. FEMS Microbiol. Ecol. 2005, 52, 21-29. [CrossRef]

91. Zhang, K.; Shi, Y.; Cui, X.; Yue, P.; Li, K.; Liu, X.; Tripathi, B.M.; Chu, H. Salinity is a key determinant for soil microbial communities in a desert ecosystem. mSystems 2019, 4, e00225-18. [CrossRef]

92. Hallmann, C.; Stannek, L.; Fritzlar, D.; Hause-Reitner, D.; Friedl, T.; Hoppert, M. Molecular diversity of phototrophic biofilms on building stone. FEMS Microbiol. Ecol. 2013, 84, 355-372. [CrossRef]

93. Urzì, C.; De Leo, F.; Krakova, L.; Pangallo, D.; Bruno, L. Effects of biocide treatments on the biofilm community in Domitilla's catacombs in Rome. Sci. Total Environ. 2016, 572, 252-262. [CrossRef]

94. Rossi, F.; Micheletti, E.; Bruno, L.; Adhikary, S.P.; Albertano, P.; Philippis, R.D. Characteristics and role of the exocellular polysaccharides produced by five cyanobacteria isolated from phototrophic biofilms growing on stone monuments. Biofouling 2012, 28, 215-224. [CrossRef]

95. Adessi, A.; Cruz de Carvalho, R.; De Philippis, R.; Branquinho, C.; Marques da Silva, J. Microbial extracellular polymeric substances improve water retention in dryland biological soil crusts. Soil Biol. Biochem. 2018, 116, 67-69. [CrossRef]

96. Nowicka-Krawczyk, P.; Żelazna-Wieczorek, J.; Koźlecki, T. Silver nanoparticles as a control agent against facades coated by aerial algae-a model study of Apatococcus lobatus (green algae). PLoS ONE 2017, 12, e0183276. [CrossRef]

97. Gambino, M.; Ali Ahmed, M.A.; Villa, F.; Cappitelli, F. Zinc oxide nanoparticles hinder fungal biofilm development in an ancient Egyptian tomb. Int. Biodeterior. Biodegrad. 2017, 122, 92-99. [CrossRef]

98. Saiz-Jimenez, C.; Miller, A.Z.; Martin-Sanchez, P.M.; Hernandez-Marine, M. Uncovering the origin of the black stains in Lascaux Cave in France. Environ. Microbiol. 2012, 14, 3220-3323. [CrossRef] 
99. Hall, C.W.; Mah, T.F. Molecular mechanisms of biofilm-based antibiotic resistance and tolerance in pathogenic bacteria. FEMS Microbiol. Rev. 2017, 41, 276-301. [CrossRef]

100. Flemming, H.C.; Wingender, J. The biofilm matrix. Nat. Rev. Microbiol. 2010, 8, 623-633. [CrossRef]

101. Zhu, T.; Dittrich, M. Carbonate precipitation through microbial activities in natural environment, and their potential in biotechnology: A review. Front. Bioeng. Biotechnol. 2016, 4, 4. [CrossRef]

102. Miller, A.Z.; Laiz, L.; Gonzalez, J.M.; Dionísio, A.; Macedo, M.F.; Saiz-Jimenez, C. Reproducing stone monument photosynthetic-based colonization under laboratory conditions. Sci. Total Environ. 2008, 405, 278-285. [CrossRef]

103. Miller, A.Z.; Liaz, L.; Dionisio, A.; Macedo, M.F.; Saiz-Jimenez, C. Growth of phototrophic biofilms from limestone monuments under laboratory conditions. Int. Biodeterior. Biodegrad. 2009, 63, 860-867. [CrossRef]

104. Vázquez-Nion, D.; Rodríguez-Castro, J.; López-Rodríguez, M.C.; Fernández-Silva, I.; Prieto, B. Subaerial biofilms on granitic historic buildings: Microbial diversity and development of phototrophic multi-species cultures. Biofouling 2016, 32, 657-669. [CrossRef] [PubMed]

105. Noack-Schönmann, S.; Bus, T.; Banasiak, R.; Knabe, N.; Broughton, W.J.; Den Dulk-Ras, H.; Hooykaas, P.J.; Gorbushina, A.A. Genetic transformation of Knufia petricola A95-a model organism for biofilm-material interactions. AMB Express 2014, 4, 80. [CrossRef] [PubMed]

106. Nai, C.; Wong, H.Y.; Pannenbecker, A.; Broughton, W.J.; Benoit, I.; de Vries, R.P.; Gueidan, C.; Gorbushina, A.A. Nutritional physiology of a rock-inhabiting, model microcolonial fungus from an ancestral lineage of the Chaetothyriales (Ascomycetes). Fungal Genet. Biol. 2013, 56, 54-66. [CrossRef] [PubMed]

107. Seiffert, F.; Bandow, N.; Bouchez, J.; von Blanckenburg, F.; Gorbushina, A.A. Microbial colonization of bare rocks: Laboratory biofilm enhances mineral weathering. Procedia Earth Planet 2014, 10, 123-129. [CrossRef]

108. Seiffert, F.; Bandow, N.; Kalbe, U.; Milke, R.; Gorbushina, A.A. Laboratory tools to quantify biogenic dissolution of rocks and minerals: A model rock biofilm growing in percolation columns. Front. Earth Sci. 2016, 4, 31. [CrossRef]

109. Grinberg, M.; Orevi, T.; Kashtan, N. Bacterial surface colonization, preferential attachment and fitness under periodic stress. PLoS Comput. Biol. 2019, 15, e1006815. [CrossRef] [PubMed]

110. Chertov, O.; Gorbushina, A.A.; Deventer, B. A model for microcolonial fungi growth on rock surfaces. Ecol. Modell 2004, 177, 415-426. [CrossRef]

111. Porada, P.; Lenton, T.; Pohl, A.; Weber, B.; Mander, L.; Donnadieu, Y.; Beer, C.; Pöschl, U.; Kleidon, A. High potential for weathering and climate effects of non-vascular vegetation in the Late Ordovician. Nat. Commun. 2016, 7, 12113. [CrossRef]

112. Porada, P.; Pöschl, U.; Kleidon, A.; Beer, C.; Weber, B. Estimating global nitrous oxide emissions by lichens and bryophytes with a process-based productivity model. Biogeosciences 2017, 14, 1593-1602. [CrossRef]

113. Porada, P.; Weber, B.; Elbert, W.; Pöschl, U.; Kleidon, A. Estimating global carbon uptake by lichens and bryophytes with a process-based model. Biogeosciences 2013, 10, 6989-7033. [CrossRef]

114. Porada, P.; Weber, B.; Elbert, W.; Pöschl, U.; Kleidon, A. Estimating impacts of lichens and bryophytes on global biogeochemical cycles. Global Biogeochem. Cy 2014, 28, 71-85. [CrossRef]

(C) 2019 by the authors. Licensee MDPI, Basel, Switzerland. This article is an open access article distributed under the terms and conditions of the Creative Commons Attribution (CC BY) license (http://creativecommons.org/licenses/by/4.0/). 